\title{
Croatian ESP vocational high school pupils and university students' habits of using online sources
}

\author{
Brankica Bošnjak Terzić \\ Technical School Ruđer Bošković \\ Getaldićeva 4, Zagreb, Croatia \\ Department of Technical Foreign Languages, Faculty of Mechanical \\ Engineering and Naval Architecture, University of Zagreb \\ Ivana Lučića 5, Zagreb, Croatia \\ brankica.bosnjakterzic@inet.hr \\ Ana Gabrijela Blažević \\ Department of Romance Studies, \\ Faculty of Humanities and Social Sciences, University of Zagreb \\ Ivana Lučića 3, Zagreb, Croatia \\ agblazev@ffzg.hr; anablazevic@gmail.com
}

\section{Summary}

Information literacy as a set of abilities needed to recognize, locate, evaluate and effectively use needed information is extremely important in education, especially in English for Technical Purposes classes due to their specific content and the rapid technological changes connected to it. For this reason, this research has been conducted trying to determine Croatian English for Specific Purposes (ESP) vocational high school pupils and university students' habits of using online sources in ESP classes and the frequency of using online sources in translation. Furthermore, the aim was to get insight into their IL background and expectations about being educated on IL by ESP teachers. The results of the study presented in this paper show that Croatian ESP vocational school pupils and university students have quite high perception of their abilities regarding their IL but their usage of online sources for ESP needs has proven to be low and not specific enough for a meaningful learning.

Keywords: information literacy, Croatian ESP pupils and students, online sources, translation

\section{Introduction}

Information literacy (IL) as a set of abilities needed to recognize, locate, evaluate and effectively use needed information is a prerequisite for the use of modern information services (Lasić-Lazić \& László, 2014). There are numerous studies showing that the Internet is used increasingly for educational purposes (Lubens, 1998, 1999; Jones \& Madden, 2002) and it is becoming the main 
information source (Browne, Freeman \& Williamson, 2000; Paris, 2002), but often without any formal training in IL (Fidel et. al., 1999; Grimer \& Boening, 2001; Jones \& Madden, 2002; Metzger, Flanagin \& Zwarun, 2003, Frazer, 2010).

Studies about vocational high school pupils and university students' IL suggest they prefer online sources over printed ones, but also that they have difficulties evaluating found information and they have poor searching skills (for a literature review, see Julien \& Barker, 2009). Although most of them started to use the Internet early and are heavy and capable users of it (Jones \& Madden, 2002), their processing of information is superficial and aims at the quantity of the data and not the quality and critical explanation which are bases for meaningful, deep and true learning (Lubans, 1999; Metzger, Flanagin \& Zwarun, 2003). That represents a gap regarding teachers' expectations of the used sources (Grimer \& Boening, 2001; Lasić-Lazić, Špiranec \& Banek Zorica; 2012) and has important implications on students' academic work, learning and professional development since the Internet contains information of very diverse quality (Špiranec, 2004) and even biased, manipulated or inaccurate information (Alexander \& Tate, 1999; Flanagin \& Metzger, 2000; Metzger, Flanagin \& Zwarun, 2003).

Due to the all above mentioned, many researchers consider IL an educational imperative essential for lifelong learning (Lau, 2006; Špiranec \& Banek Zorica, 2008). That is why many educators are incorporating it into their curricula, that is, in a real context and with concrete students' needs, which helps and facilitates the learning of the information skills (Eisenberg, 2008). For example, Seljan (2011) in her research of evaluating online language resources and tools for Croatian language states that Croatian students are very interested in the use of translation technology, especially in translating domain specific texts (like ESP), but a further research also shows that translations performed by Google Translate from English to Croatian are of lower grade than the ones in opposite direction (Seljan, Brkić \& Kuciš, 2011), which is a fact students should be aware of.

Since Technical English for Specific Purposes (ESP) classes deal with very specific content prone to rapid change and development, internet sources are of crucial importance for a quality education. This research was conducted among Croatian ESP vocational high school pupils and university students with the aim of getting some insight into their IL as a very important reference point for improving ESP teaching.

\section{Purpose of the Study}

The aim of this study was to determine Croatian pupils and students' ESP habits and beliefs about using online sources for educational purposes, frequency of used online sources when translating ESP texts and their background on IL 
education. Furthermore, the aim was to get insight into their expectations about being educated on IL by ESP teachers.

\section{Hypothesis}

In regards to the aim of the research, the study hypothesizes the following:

a) Croatian pupils and students are heavy internet users, both for general and educational purposes.

b) Most participants didn't have any previous IL training, but still are aware of the importance of being educated about IL.

c) The main criteria for choosing an online source is the ranking on the search engine and the web page design.

d) One of the most frequent sources used in translation among ESP pupils and students is Google translate.

e) University students will use more specialized online sources than vocational high school pupils in translation process.

\section{Methodology}

\section{Participants}

The research included 63 participants $(\mathrm{N}=63), 30$ pupils (all male) and 33 students $(\mathrm{N}=33 ; 22$ males and 11 females). Pupils (age 17) attended the third grade at Technical School Ruđer Bošković studying ESP for the first time. Two classes which participated in the research were Technicians for Mechatronics. Approval from the school's principal was gained and all parents signed the approval consent for the research.

The students (age 20-21) were second year students at the Faculty of Mechanical Engineering and Naval Architecture. Technical English is taught at the second and the third year at the Faculty. Out of 33 students; 22 were studying ESP for the first time in their education, 7 studied for 2 years and 3 for three years.

For both groups the average number of learning English was 10.51 years $(\mathrm{SD}=1.6, \mathrm{Mo}=11)$. Conducted t-test confirmed that there was no statistical difference between both groups regarding the duration of learning English.

\section{Instrument}

The instrument consisted of two parts. The first part included ESP text participants had to translate. Each group got different text according to their language level while the second part was the questionnaire, same for the both groups. The text for pupils was intended for the intermediate level of language knowledge, covering the basics of Pneumatics. The text for students was intended for the upper-intermediate level of language knowledge, covering the basics of the Gasification Process. Participants were sent texts that had to be translated from English to Croatian using only online sources. Teachers didn't suggest which online sources they could use. 
The second part included a questionnaire in Croatian, which consisted of 19 questions of different types: multiple choices, Likert scale questions, short answers, and yes/no questions. The questionnaire was divided in 3 parts. The first part of the questionnaire included information about students and pupils' education and their beliefs in regards to using online sources. The second part captured insight into students and pupils' IL. The last part covered the frequency of the internet and online sources use for ESP classes and classes in general.

\section{Results $^{1}$ and discussion}

\section{General and educational internet use}

Out of 63 participants, 62 (98\%) participants answered that they had internet access. About the time they spend on the computer, out of 63 participants in the study, 24 (38\%) use computer between 1 and 3 hours, 20 (32\%) use computers for more than 3 hours, $12(19 \%)$ use it for an hour and only $7(11 \%)$ students use computer 30 minutes a day.

The answers to the questions how often they use the Internet for general educational purposes and for ESP classes are shown in the Table 1.

Table 1. Usage of the Internet for educational purposes

\begin{tabular}{|l|c|c|}
\hline $\begin{array}{c}\text { Usage of the } \\
\text { Internet for... }\end{array}$ & $\begin{array}{c}\text {...general educational } \\
\text { purposes }\end{array}$ & ...ESP \\
\hline Never & 0 & 7 \\
\hline Rarely & 7 & 28 \\
\hline Sometimes & 25 & 3 \\
\hline Often/very often & 31 & 13 \\
\hline
\end{tabular}

It's interesting to note that despite almost half of the participants ( $N=31,49 \%)$ stated they used the Internet often and very often for educational purposes, and slightly less than half $(\mathrm{N}=25,40 \%)$ used it sometimes (altogether $89 \%$ ), the use of the Internet for ESP classes dropped dramatically and more than half of the participants $(\mathrm{N}=35,56 \%)$ used it rarely or never.

This supports the first hypothesis, but since the characteristics of Technical LSP (Language for Specific Purposes) impose the Internet as an essential tool, the gap between the use of the Internet for general educational purposes and ESP also shows that the possible benefits of the Internet usage in ESP classes are not properly exploited yet, which leads to the conclusion that there is still much to do in that area.

\footnotetext{
${ }^{1} \mathrm{~A}$ t-test was conducted for every item to see if there was any statistically significant difference between pupils and students. Since the significant difference was established only in one item, this chapter will present the results of both groups together, only indicating their difference when it was found statistically significant.
} 
Participants were also asked to grade their satisfaction with online sources in regards to their educational-informational needs. Responses are shown in Chart 1.

Chart 1. Satisfaction with online sources for educational-informational needs

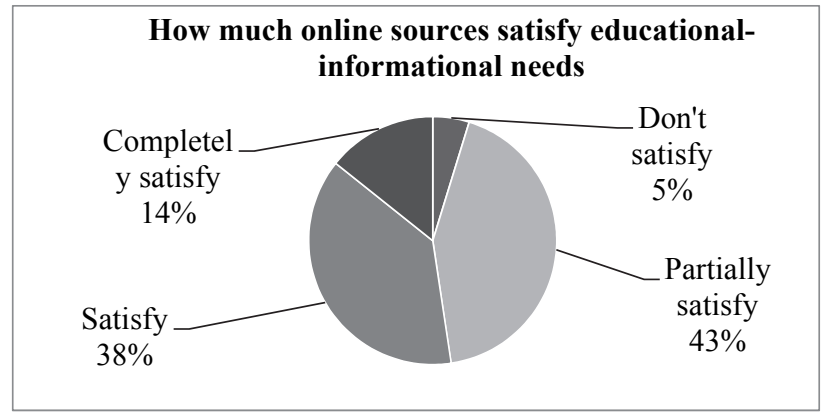

Since only $3(5 \%)$ of the participants said that online sources didn't fulfil their educational-informational needs, the results indicate one more time the wellknown potential of the Internet for educational purposes, which is corroborated with the fact that 33 participants (52\%) said sources satisfied or completely satisfied their needs. Still, it is important not to disregard 27 participants (43\%), who stated that online sources only partially satisfied their educational-informational needs. This could mean two things: either they also value traditional sources or they are not finding on the Internet everything they need, or probably, the combination of both. Knowing the importance of IL for getting the best of the Web without being overwhelmed by the amount of available information, the next aim of the questionnaire was to check participants' background and basic knowledge on IL.

\section{Information literacy: background and awareness}

When questioned about their previous formal education regarding informational literacy, only $8(13 \%)$ of the participants said they had some instructions on IL $(\mathrm{N}=6$ in high school, $\mathrm{N}=2$ in elementary school), which confirmed the first part of the second hypothesis of the research. Despite that, when participants were asked to assess their capability to find information on the Internet on the scale from 1 (I am not capable) to 5 (I am completely capable), they assessed their capability quite high, as it's shown in the Chart 2 .

Participants rated their capability with the average score $4.05(\mathrm{Mo}=4$, SD $=.888)$. While 28 participants $(44 \%)$ assessed to be capable (4), $21(33 \%)$ assessed themselves as extremely capable (5) and 11 participants (18\%) as partially capable (3). The lowest assessment (2) was given by two participants $(3 \%)$ and only one participant (2\%) assessed himself as not capable (1). 
Chart 2. Capability in finding information online

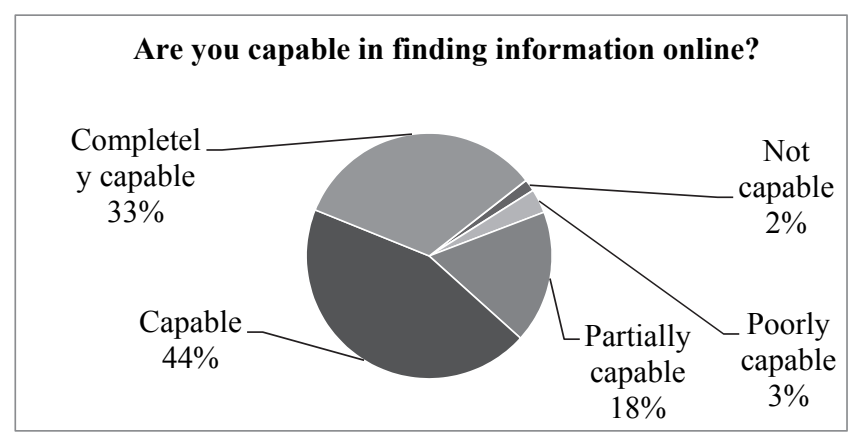

Accordingly, to the question 'Is it difficult to find needed information on the Internet?' 50 students (79\%) answered that it was easy while $11(18 \%)$ claimed that sometimes it was difficult. Only 2 students (3\%) found it difficult. The given explanations were that difficulty depended on the content they were looking for.

Although a very high percentage (77\%) of the participants found that they were capable or completely capable to find information on the Internet, still $65 \%$ $(\mathrm{N}=41)$ of all participants thought that education in IL was necessary, while $17.5 \%(\mathrm{~N}=11)$ thought that education was not necessary and the same number that they weren't sure, which supports the second part of the second hypothesis. When asked whether their language teacher should include IL training as part of his/her ESP classes several arguments were given. 29 (46\%) participants agreed that ESP teachers should give some IL education and they supported the argument with the following: a language teacher knows what information is correct and where to find it; that kind of training would help them translate specialized text easier and would improve their learning. A total of $15(23.8 \%)$ participants said that a language teacher shouldn't do that since that wasn't his/her role, while 19 (30.1\%) participants weren't sure about the role of an ESP language teacher regarding IL.

Regarding the search for information, 28 (45\%) of the participants said they looked for the needed information until they found it, 21 (33\%) claimed they only checked the results that appeared on the first page of the search engine and $7(11 \%)$ that they looked at the results on the first three pages. Surprisingly, there were 7 (11\%) participants who stated they only looked at the first result of the search engine.

To the question whether they checked the information in more sources, altogether $24(38 \%)$ participants stated that they checked the information in more sources, while $21(33 \%)$ said that they never did that. Interestingly, 18 (29\%) participants stated that they sometimes checked information supporting their arguments that the same depended on the quality of explanation $(\mathrm{N}=13$; $20 \%)$ and the quality of translation $(\mathrm{N}=4 ; 6 \%)$. 
A few more questions of the questionnaire had the aim of getting a little insight into some other elementary aspects of participants' IL. As the second hypothesis was that participants didn't have any IL training, the expectation was that the main criteria for choosing an online source was the ranking of the page in the web searcher and the web page design, while checking the author and the date were not so popular. As is shown in Chart 3, the hypothesis was partially supported.

Chart 3. Criteria in choosing best online source

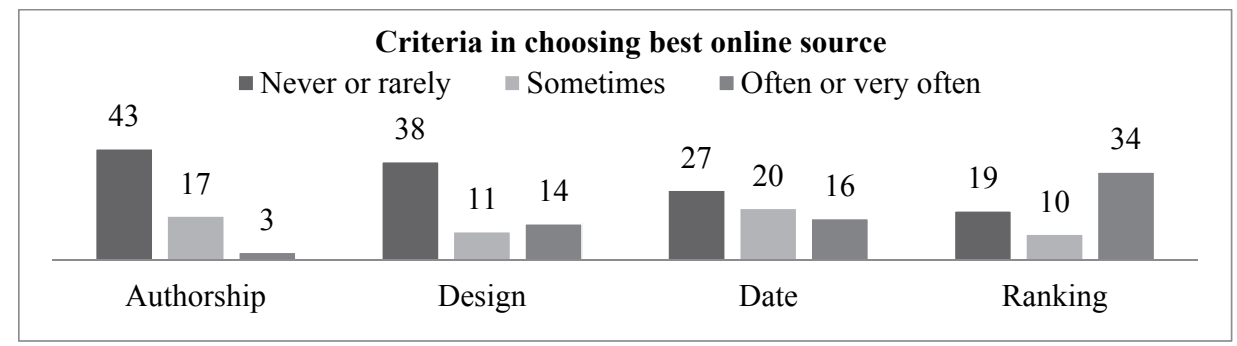

Chart 3 shows that the main criteria of the participants is the ranking of an online source in the search engine $(\mathrm{M}=3.19, \mathrm{SD}=1.24)$, while authorship is rarely checked $(\mathrm{M}=2.05, \mathrm{SD}=.99)$. About the date of the online information $(\mathrm{M}=2.70, \mathrm{SD}=1.21)$, that criteria seems to be more relevant for the participants and it's checked more often, which can be related to the field of their studies because the rapid change of technology makes some technologies quickly obsolete. Web design $(\mathrm{M}=2.33, \mathrm{SD}=1.16)$ doesn't seem to be relevant for the participants, which can be related to the type of sources they mainly use, as it will show the last part of the research.

\section{Insight into the use of online sources for ESP purposes \\ Questionnaire answers}

The third part of the questionnaire analyses the use and the frequency of online sources for the needs of ESP classes. Participants had to circle on the Likert scale from 1 (never) to 5 (very often) the frequency of online sources use for ESP classes. Even though the participants have quite high perception of their abilities regarding their IL, Table 2 shows not very high frequency of online sources use for ESP needs. Apparently, their need for online sources has proven to be low and not specific enough, especially when we take into consideration the specific sources that are needed for ESP classes.

Regarding ESP texts, it is particularly interesting to note that $89 \%(\mathrm{~N}=56)$ of the participants said they never used terminological dictionaries, while other valuable sources like mono and bilingual dictionaries, corporate web pages, web pages of professional association and manuals were used rarely. The only two types of online sources they apparently use sometimes are videos and wiki 
sources (mainly Wikipedia), while they mostly rely on online translation services.

Table 2. Average score of the online sources usage for ESP classes

\begin{tabular}{|c|c|c|c|}
\hline 0-1,49; never & 1,5-2,49; rarely & $\begin{array}{c}2,5-3,49 \\
\text { sometimes }\end{array}$ & $\begin{array}{c}3,5-4,49 \\
\text { often }\end{array}$ \\
\hline $\begin{array}{l}- \text { thesaurus } \\
(\mathrm{M}=1.06 ; \\
\mathrm{SD}=.400) \\
\text { terminological } \\
\text { dictionaries } \\
(\mathrm{M}=1.16 ; \\
\mathrm{SD}=.549) \\
\text { encyclopaedias } \\
(\mathrm{M}=1.16 ; \\
\mathrm{SD}=.578) \\
\text { blog }(\mathrm{M}=1.48 \\
\mathrm{SD}=.936)\end{array}$ & $\begin{array}{l}\text { - } \text { presentations }(\mathrm{M}=1.51 ; \mathrm{SD}=.840) \\
\text { - monolingual dictionaries }(\mathrm{M}=1.66 ; \\
\mathrm{SD}=1.173) \\
\text { - corporate web pages }(\mathrm{M}=1.68 ; \\
\mathrm{SD}=1.129) \\
\text { - } \text { books and magazines }(\mathrm{M}=1.69 ; \\
\mathrm{SD}=1.034) \\
\text { - individual web pages }(\mathrm{M}=1.71 ; \\
\mathrm{SD}=.974) \\
\text { - forums }(\mathrm{M}=1.78 ; 1.054) \\
\text { - web pages of professional associations } \\
\text { ( } \mathrm{M}=1.87 \mathrm{SD}=1.129) \\
\text { - portals }(\mathrm{M}=1.89 ; \mathrm{SD}=1.220) \\
\text { - bilingual dictionaries }(\mathrm{M}=2.00 ; \\
\mathrm{SD}=1.462) \\
\text { - } \text { manuals }(\mathrm{M}=2.02 ; \mathrm{SD}=1.284) \\
\text { - } \text { pictures }(\mathrm{M}=214 ; \mathrm{SD}=1.378 ; \\
\text { p=.010** })^{2} \\
\text { - } \text { spellcheckers }(\mathrm{M}=2.29 ; \mathrm{SD}=1.349) \\
\text { - } \text { social networks }(\mathrm{M}=2.33 ; \mathrm{SD}=1.513)\end{array}$ & $\begin{array}{l}\text { - video } \\
(\mathrm{M}=2.52 ; \\
\mathrm{SD}=1.533) \\
\text { - Wikipedia } \\
\text { and other } \\
\text { wiki sources } \\
(\mathrm{M}=3.21 ; \\
\mathrm{SD}=1.297)\end{array}$ & $\begin{array}{l}- \text { online } \\
\text { translation } \\
\text { services } \\
(\mathrm{M}=3.76 ; \\
\mathrm{SD}=1.422)\end{array}$ \\
\hline
\end{tabular}

This general low usage of online sources in ESP classes could compromise students' meaningful learning outside the classroom, so ESP teachers should work on this aspect of IL students' training. Even though, translation services could be good and fast help that can speed some translation processes or resolve some language doubts, their usage in LSP and general language classes should be seen only as an aid, since they still demand a great human effort to process, analyse and correct the received output. Furthermore, when dealing with such specific terminology as the one LSP deals with, online translation services could also be misleading. For this reason we consider that monolingual and bilingual dictionaries should be better and more used sources for ESP needs. It is unusual to note that terminological dictionaries as well as encyclopaedias and thesauruses are almost never used by Croatian ESP vocational high school pupils and students, even though they should be of crucial importance as complementary sources to the ones used in ESP classes since they are not exclusively related to the language, but to the theoretical parts of their study.

\footnotetext{
${ }^{2}$ This was the only result in the entire research in which statistically significant difference was found between pupils and students (pupils $\mathrm{M}=2.43, \mathrm{SD}=1.547$, students $\mathrm{M}=1.88, \mathrm{SD}=1.166$ ).
} 
It is also interesting to notice the low position of pictures, manuals and presentations, which could be quite useful in learning ESP. They can be very useful for example when learning about technical parts like parts of a boat, car, engine and so on. In a future and more detailed research, it would be useful to separate the use of online sources for concrete language needs and for other educational purposes, to gain more accurate insight into their habits as information consumers and to see how often they use those sources for other classes. Such results could reveal whether those sources are generally of low usage or students have special problems in using them or finding them in a second language.

\section{List of used sources while translating}

In order to see which specific online sources were used in translating ESP texts, the participants had to name the sources they used in translating the given ESP text. The Chart 4 shows which online sources were used by pupils and students.

Chart 4. Used online sources among pupils and students

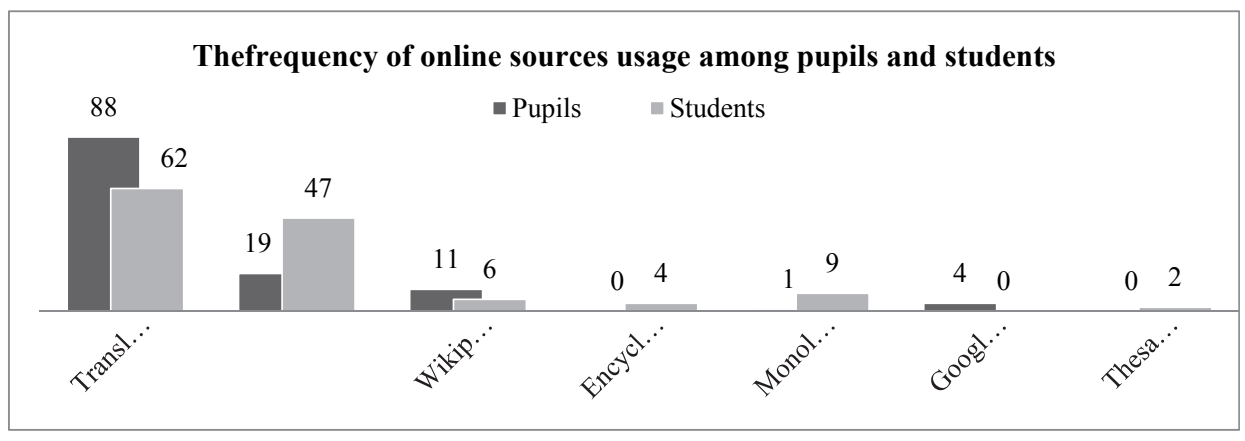

Pupils: Pupils numbered 124 uses of online sources when translating given ESP text, out of which the most frequent used online source were online translation services (88 times: Google translate 75, Etranslator 13) then bilingual dictionaries (19 times: Eudict 13, Glosbe 3, Crodict 2, English-Croatian dictionary 1). Wikipedia was selected 11 times, Google.hr 4 times and monolingual dictionary only one time (The Free Dictionary).

Students: Students searched for online help 130 times, out of which the most frequent used online sources were translation services (62: Google translate 61, Etranslator 1). Bilingual dictionaries were used 47 times (Glosbe 23, Eudict 13, Crodict 6, English-Croatian dictionary 4 and E-dictionary 1). Monolingual

\footnotetext{
3 Since The Free Dictionary (thefreedictionary.com) is an online dictionary, thesaurus and encyclopaedia, an analysis of the links showed that it was used as a dictionary/thesaurus. Because the thesaurus part is at the very end of the page, after numerous and repeated definitions of the word looked-up, we believe it was mainly used as a monolingual dictionary.
} 
dictionaries were selected 9 times (The Free dictionary 6, Cambridge dictionary 2, Vocabulary.com 1). Wikipedia was chosen 6 times, Investopedia 4 and Thesaurus (thesaurus.com) 2 times.

Comparison: The results support the fourth hypothesis, that is, Google translate has been confirmed as the most frequent used online source. The fifth hypothesis was partially confirmed. Students use more bilingual and monolingual dictionaries and other sources which are unknown to pupils (online encyclopaedias other than Wikipedia and thesaurus), but still the usage is so poor and most of it is relied on online translation services which are not the best solution for such a specific translation which ESP texts require.

This research opens the door for new researches which could investigate the validity of ESP translation to and from Croatian while using online sources and it gives an idea of needed IL education among students and pupils that can be given only by professional educationalists.

\section{Conclusion}

The conducted research has shown frequent habits of using the Internet among pupils and students for general and educational purposes. The study confirmed that most of the participants didn't have any previous IL training. Even though they self-evaluated themselves as highly capable when searching for information, they are still acknowledging the fact that IL education is desirable since online sources are not likely to be useful unless the students can locate them and know how to use them to enhance their language learning experience. This is especially important among Technical ESP students and pupils since their needs are specific in regards to the specific language they are learning and thus the choice of internet sources should be also specific in order to satisfy those needs. The research results show that Croatian ESP pupils and students present low frequency of online sources usage and are mainly oriented to Google translate.

Such results emphasize the fact that education in IL is necessary and extremely important which again heightens the role of language teachers educating students on specific language oriented sources. By implementing IL education on all levels of education, students will become critical users of online technology and will be able to choose the best online information, explanation and translation while scrolling the Internet, which is a prerequisite for a deep and meaningful learning. 


\section{References}

Alexander, Janet E.; Tate, Marsha A. Web wisdom : How to evaluate and create information quality on the Web. Hillsdale, NJ : Lawrence Erlbaum, 2009.

Browne, M. Niel, Freeman, Kari E.; Williamson, Carrie L. The importance of critical thinking for student use of the Internet. // College Student Journal, 34(2000), 3, 391-398.

Eisenberg, Michael B. Information Literacy : Essential Skills for the Information Age. // DESIDOC Journal of Library \& Information Technology. 28(2008), 2, 39-47.

Fidel, Raya et. al. A Visit to the Information Mall : Web Searching Behavior of High School Students. // Journal of the American Society for Information Science. 50(1999), 1, 24-37.

Flanagin, Andrew J.; Metzger, Miriam J. Perceptions of Internet information credibility. // Journalism and Mass Communication Quarterly. 77(2000), 515-540.

Frazer, Megan. Students Leave High School Without Necessary Information Literacy Skills. Massachusetts School Library Association, 2010. http://maschoolibraries.org/content/view/ 129/105/ (29.5.2015).

Grimer, Deborah J.; Boening, Carl H. Worries with the Web: A Look at Student Use of Web Resources. // College \& Research Libraries 2001, 11-[22].

Julien, Heidi; Barker, Susan. How high-school students find and evaluate scientific information: A basis for information literacy skills development. // Library \& Information Science Research. 31(2009), 1, 12-17.

Jones, Steve; Madden, Mary A. The Internet goes to college : how students are living in the future with today's technology. Washington, D.C. : Pew Internet \& American Life Project, [2002].http://www.pewinternet.org/files/old-media/Files/Reports/2002/PIP_College_Report. pdf.pdf (18.5.2015).

Lasić-Lazić, Jadranka; Špiranec, Sonja; Banek Zorica, Mihaela. Izgubljeni u novim informacijskim okruženjima-pronađeni $\mathrm{u}$ informacijskom opismenjavanju. // Medijska istraživanja. 18(2012), 1, 125-143.

Lasić-Lazić, Jadranka.; László, Marija. Mjerila informacijske (ne)pismenosti. // Informacijska tehnologija u obrazovanju : znanstvena monografija / Lasić-Lazić, J. (ed.). Zagreb : Zavod za informacijske studije, 2014, 223-234.

Lau, Jesus. Guidelines on information literacy for lifelong learning : final draft, reviewed July 30 , 2006. http://www.ifla.org/files/assets/information-literacy/publications/ifla-guidelines-en.pdf (28.5.2015).

Lubans, John. How First-Year University Students Use and Regard Internet Resources. (1998) http://www.lubans.org/docs/1styear/firstyear.html (28.5.2015).

Lubans, John. Key Findings on Internet Use among Students. (1999) http://www.lubans.org/ docs/key/key.html (28.5.2015).

Metzger, Miriam J.; Flanagin, Andrew J.; Zwarun, Lara. College student Web use, perceptions of information credibility, and verification behavior. // Computers \& Education. 41(2003), 271290.

Paris, Paul G. Critical Thinking and the Use of the Internet as a Resource. // International Education Journal. 4(2002), 1, 30-41.

Seljan, Sanja; Brkić, Marija; Kuciš, Vlasta. Evaluation of Free Online Machine Translations for Croatian-English and English-Croatian Language Pairs // INFuture2011: The Future of Information Sciences - Information Sciences and e-Society. Zagreb : Department of Information Sciences, 2011, 331-344.

Seljan, Sanja. Translation Technology as Challenge in Education and Business. // Informatologia. 44(2011), 4, 279-286.

Špiranec, Sonja. Virtualna učionica NSK ili kako su knjižnice zakucale na vrata e-učenja. // Edupoint. 25(2004), 8. http://eprints.rclis.org/5757/1/Edupoint_25_Spiranec.pdf (29.5.2015)

Špiranec, Sonja; Banek Zorica, Mihaela. Informacijska pismenost: teorijski okvir i polazišta. Zagreb : Zavod za informacijske studije Odsjeka za informacijske znanosti Filozofskog fakulteta Sveučilišta u Zagrebu, 2008. 